JIEBAR : Journal of Islamic Education: Basic and Applied Research

Vol. 01, Nomor 02, Oktober 2020 https://www.e-journal.stit-islamic-village.ac.id/jiebar

\title{
Character Education Curriculum in the Government of Indonesia Strengthening Character Education Program
}

\section{Kurikulum Pendidikan Karakter Prespektif Program Penguatan Pendidikan Karakter Pemerintah Indonesia}

\author{
Ahmad Buchori Muslim \\ STIT Islamic Village Tangerang \\ Email: ahmadbuchori23@gmail.com
}

Received: Agustus, 2020.

Accepted: September, 2020.

Published: Oktober, 2020.

\begin{abstract}
Character education is ethics education, character education, moral education, and value education which aims to shape each individual into a human with character, namely by planting positive character values so that they can be internalized in oneself and manifest in real action. Character education plays an important role in aspects of human life because being a human being with character will be able to live in a wider community dimension with a firm life principle. The Indonesian government has designed a program aimed at shaping cultured, quality, and character Indonesian people. In Presidential Regulation Number 87 of 2017 concerning strengthening character education, the government requires every educational institution in Indonesia both formal, informal, and non-formal to carry out the "Penguatan Pendidikan Karakter" (PPK) movement. The values that need to be instilled in character education include aspects of religion, humanity, and citizenship. In implementing character education, the principal must also involve all elements of the family, community, and school, and this education must be carried out continuously because character education is an education that will never end.
\end{abstract}

Keywords: Curriculum, Character Education

\section{ABSTRAK}

Pendidikan karakter merupakan pendidikan etika, pendidikan budi pekerti, pendidikan moral dan pendidikan nilai yang bertujuan untuk membentuk setiap individu menjadi 
manusia yang berkarakter, yaitu dengan penanaman nilai-nilai karakter positif agar dapat terinternalisasi dalam diri dan terwujud dalam tindakan nyata. Pendidikan karakter mempunyai peranan penting dalam aspek. kehidupan manusia, karena dengan menjadi manusia yang berkarakter maka akan dapat hidup dalam dimensi masyarakat luas dengan memegang prinsip bidup yang teguh. Pemerintah Indonesia telah merancang program yang bertujuan untuk membentuk manusia Indonesia yang berbudaya, berkualitas dan berkarakter. Dalam Peraturan Presiden Nomor 87 Tabun 2017 tentang penguatan pendidikan karakter, pemerintah mewajibkan kepada setiap lembaga satuan pendidikan di Indonesia baik formal, informal dan non-formal untuk melaksanakan gerakan Penguatan Pendidikan Karakter (PPK) tersebut. Nilai-nilai yang perlu ditanamkan dalam pendidikan karakter meliputi aspek keagamaan, kemanusiaan, dan kewarganegaraan. Dalam melaksanakan pendidikan karakter juga memiliki prinsip barus melibatkan selurub elemen keluarga, masyarakat dan sekolah, dan pendidikan tersebut juga harus dilakukan secara terus menerus, sebab pendidikan karakter adalab pendidikan yang tidak akan pernab berakbir.

Kata Kunci: Kurikulum, Pendidikan Karakter

\section{PENDAHULUAN}

Pada hakikatnya tujuan pendidikan secara umum yang ada di seluruh dunia yaitu untuk menjadikan manusia yang cerdas, pintar dan baik (Sudrajat, 2011: 47). Secara filosofis, dunia pendidikan dipandang dan diharapkan dapat menjadi alat atau wadah untuk dapat mencerdaskan dan membangun juga membentuk karakter seseorang agar menjadi baik (Dahliyana, 2017: 54). Peran pendidikan yang dipandang sebagai salah satu bidang kehidupan umat manusia yaitu untuk menciptakan generasi yang berpengetahuan, bijaksana dan berkarakter (Rachmadyanti, 2017).

Dalam pendidikan karakter terdapat pembelajaran dan pengajaran mengenai moral dan nilai seseorang, yang meliputi 1) pendidikan emosional, 2) pendidikan keterampilan hidup, 3) pencegahan kekerasan, 4) pembelajaran sosial, 5) penalaran nilai dan moral dan 6) pengembangan kognitif (Raharjo, 2010). Penanaman dan pembentukan karakter pada anak harus di lakukan sejak dini, karena hal ini merupakan upaya untuk mempersiapkan generasi penerus bangsa yang berkarakter serta berpengetahuan tinggi yang diharapkan akan dapat memimpin bangsa di masa mendatang yang senantiasa menjujung tinggi

JIEBAR : Journal of Islamic Education: Basic and Applied Research Vol. 01, Nomor 02, Oktober2020 
nilai-nilai luhur dengan budi pekerti dan perilaku yang baik (Ainiyah, 2013). Pendidikan karakter adalah tanggung jawab setiap elemen dan tanggung jawab bersama yang meliputi keluarga, masyarakat dan satuan pendidikan baik formal, informal dan nonformal (Ramdani, 2018).

Sebagai bangsa yang bermartabat, Indonesia harus memiliki dan dapat mencetak juga mebentuk manusia-manusia yang beragama dan berbakti kepada Tuhan Yang Maha Esa, cerdas, terampil, bijaksana, berbudi pekerti luhur, berakhlak mulia, dan berperadaban tinggi. Maka dari itu sangat dibutuhkan pembangunan pendidikan yang berorientasi pada nilai-nilai karakter bangsa, yang tidak hanya menitik beratkan pada aspek intelektual kognitif, nalar atau logika saja namun juga harus memperhatikan dan menghubungkan masalah moral dan keluhuran budi pekerti (Sudarsana \& Herawan, 2017: 226-227).

Di era globalisasi saat ini dimana teknologi telah berkembang sangat pesat menjadikan banyaknya pertukaran informasi dan budaya datang dan pergi tanpa ada batasan. Bayaknya budaya-budaya yang tidak sesuai dengan nilai-nilai karakter bangsa dapat masuk dan ditelan mentah-mentah oleh masyarakat sehingga akan menimbulkan krisis moral pada suatu bangsa (Afandi, 2011). Maka dari itu pendidikan karakter sangat penting bagi keberlangsungan dan keunggulan sebuah bangsa. Menyikapi hal ini maka pemerintah Indonesia mengatur gerakan penguatan pendidikan karakter yang diatur dalam Peraturan Presiden Nomor 87 Tahun 2017 Tentang Penguatan Pendidikan Karakter (PPK) yang wajib diterapkan dalam setiap satuan pendidikan formal, informal dan nonformal. Program penguatan pendidikan karakter bertujuan untuk membentuk nilai-nilai karakter bangsa agar terinternalisasi dalam diri dan terwujud dalam perilaku nyata (Majid, 2019: 43) juga untuk meningkatkan mutu penyelenggaraan dan hasil pendidikan (Rachmadyanti, 2017: 204).

\section{METODE PENELITIAN}

Penelitian ini merupakan penelitian kepustakaan atau kajian literatur (library research), dengan metode pendekatan tematik sebagai pendekatan dalam pengumpulan dan pembahasan datanya. Sedangkan teknis analisis data yang digunakan adalah analisis isi (content analysis), yaitu teknis penelitian yang 
digunakan untuk menganalisa makna yang terkandung di dalam data yang dihimpun melalui riset kepustakaan.

\section{HASIL DAN PEMBAHASAN}

\section{A. Pengertian Pendidikan Karakter}

Neolaka (2017: 11) berpendapat bahwa pendidikan adalah perubahan kebiasaan berprilaku, berfikir serta sifat seorang individu akibat adanya pengaruh lingkungan. Syam (2019: 11) berpendapat pendidikan adalah proses berkembangnya seseorang dalam kecakapan yang meliputi perilaku dan sikap yang berlaku dalam masyarakat. Karakter berarti sifat, watak, akhlak, atau budi pekerti (Hartatik, 2014: 38), karakter juga merupakan ciri khas yang dapat membedakan antara seseorang dengan orang lain (Sulastri, 2018: 10). Menurut Rosidatun (2018: 20) Karakter adalah nilai dasar yang ada didalam diri individu, yang terbentuk baik dari keturunan ataupun pengaruh lingkungan dan tergambar dalam perilaku dan sikapnya di kehidupan sehari-hari.

Yaumi (2014: 10) Pendidikan karakter merupakan usaha sadar dan disengaja untuk mengembangkan karakter yang baik yang ada dalam diri individu yang sesuai dengan nilai yang ada di masyarakat. Nilai-nilai tersebut merupakan nilai-nilai kemanusiaan yang meliputi, keberanian, rendah hati, kesetaraan, kejujuran, tanggung jawab, dan penghargaan terhadap orang lain.

Haynes (Sukiyat, 2020) berpendapat bahwa pendidikan karakter merupakan bentuk gerakan nasional guna menciptakan lembaga-lembaga pendidikan untuk mengembangkan budi pekerti, kepedulian dan rasa tanggung jawab seseorang dengan penanaman karakter yang baik serta pembiasaan dan keteladanan yang berdasar pada standar nilai dan moral yang disepakati bersama.

Husna Nashihin (2017) mengutip dari buku panduan pendidikan karakter yang ditulis oleh Kemdiknas, menjelaskan bahwa pendidikan karakter merupakan pendidikan budi pekerti, moral, nilai dan pendidikan tentang sikap atau watak yang mempunyai tujuan agar seluruh warga sekolah dapat membedakan baik dan buruk, dapat menjadi teladan, dan dapat berbuat baik yang tergambar dalam kehidupan sehari-hari. Beliau juga berpendapat bahwa pendidikan karakter adalah proses pendidikan yang bertujuan agar manusia memiliki etika serta nilai moral sehingga mereka mampu untuk hidup sesuai dengan standar etika moral yang ada dalam masyarakat. 
Lickona dalam Sukiyat (2020: 72) menjelaskan bahwa pendidikan karakter adalah pendidikan budi pekerti untuk membentuk karakter atau kepribadian seseorang yang hasilnya dapat terlihat dalam perilaku nyata seharihari, seperti sikap adil, jujur, bertanggung jawab, kerja keras, menghargai sesama, dan perbuatan baik lainnya. Menurutnya ada tiga komponen dalam pendidikan karakter yaitu:

1. Pengetahuan mental (moral knowing) meliputi kesadaran moral, mengetahui nilai-nilai moral, mengambil sudut pandang, pertimbangan moral, membuat keputusan dan mengenal diri sendiri.

2. Perasaan tentang moral (moral feeling) adalah aspek perasaan yang harus ditanamkan, meliputi nurani, percaya diri, empati, kerendahan hati, mampu mengontrol diri, dan kerendahan hati.

3. Perbuatan moral (moral acting) merupakan implikasi dari pengetahuan moral yang terwujud dalam tindakan nyata, meliputi keinginan, kompetensi dan kebiasaan.

Dengan memperhatikan hal-hal tersebut, seseorang diharapkan dapat memenuhi 4 aspek yaitu: 1) mengetahui kebaikan (knowing the good), 2) mencintai kebaikan (loving the good), 3) menginginkan kebaikan (desiring the good), dan 4) mengerjakan kebaikan (acting the good).

Berdasarkan beberapa pendapat yang mengemukakan tentang pendidikan karakter diatas, dapat disimpulkan bahwa pendidikan karakter adalah usaha sadar yang dilakukan untuk membentuk mental dan karakter atau sifat seorang individu sebagai ciri khas antar individu satu dengan lainnya yang tergambar dalam perilaku di kehidupan sehari-hari serta sesuai dengan nilai dan moral yang berlaku di dalam masyarakat. Dimana karakter terebut meliputi, kejujuran, tanggung jawab, sopan santun, menghargai dan menghormati orang lain, percaya diri, rendah hati, dan perilaku baik lainnya ( Sukiyat, 2020).

\section{B. Urgensi Pendidikan Karakter}

Karakter adalah satu hal yang penting dan mendasar bagi manusia, sebab karakter adalah pembeda antara manusia dengan makhluk lainnya. Manusia yang berkarakter adalah manusia yang berakhlak baik, berbudi pekerti luhur, menjujung sopan santun, jujur, dan berlaku baik terhadap manusia lain. Karena begitu pentingnya sebuah karakter maka lembaga pendidikan 
mempunyai kewajiban untuk membentuk manusia-manusia yang berkarakter melalui proses pembelajaran (Zubaedi, 2011), hal tersebut berhubungan dengan tujuan pendidikan yaitu menjadikan peserta didik sebagai individu yang berkarakter (Farida, 2016).

Pendidikan karakter berarti bentuk usaha yang sistematis, sungguhsungguh dan terus menerus untuk membangun kesadaran dan keyakinan seseorang bahwa tidak akan ada masa depan bagi orang-orang yang tidak memiliki karakter yang kuat (Farida, 2016). Masa depan tidak akan terwujud jika tanpa adanya rasa keingin tahuan, kejujuran, kegigihan, kedisiplinan, semangat, rasa tanggung jawab, rasa percaya diri, dan optimis. Farida (2016) juga berpendapat bahwa pengembangan pendidikan karakter dipengaruhi oleh diri sendiri, keluarga, masyarakat sekitar, lingkungan atau wilayah. Sebab pengaruh-pengaruh tersebut maka karakter seseorang akan terbentuk dan dapat di lihat padaperilaku serta sikapnya. Dengan demikian diharapkan masyarakat dapat menyadari bahwa begitu pentingnya pendidikan karakter sebagai proses pembentukan perilaku, akhlak, serta pengayaan moral yang dengan ini lembaga pendidikan dapat mempersiapkan dan menyediakan figur keteladanan serta dapat menciptakan lingkungan yang mendukung dan membantu suasana pembelajaran atau pelaksanaan pendidikan karakter tersebut secara menyeluruh sehingga tujuan pendidikan yang telah dicitacitakan dapat terwujud.

Menurut Muin dalam Ainissyifa (2014: 7) terdapat 6 pilar utama dalam pendidikan karakter yaitu penghormatan, tanggung jawab, kesadaran berwarganegara, kedaila dan kejujuran, kepedulian dan kemauan berbagi, serta kepercayaan. Menurut Julaiha (2014) di dalam dunia pendidikan, pendidikan karakter tidak hanya sebatas mengajarkan tentang benar dan salah terhadap sesuatu. Lebih dari itu pendidikan karakter juga menanamkan babit (kebiasaan) mengenai nilai-nilai yang baik, sehingga peserta didik dapat memahami (kognitif), merasakan (afektif) dan melakukan (psikomotorik). Sehingga ketiga ranah tersebut dapat tercapai dengan baik dan tujuan pendidikan pun dapat di raih secara optimal.

Mengingat begitu urgennya seseorang untuk mendapatkan pendidikan karakter maka sangat penting untuk menanamkan nilai-nilai pendidikan karakter sedini mungkin pada anak, terutama di lingkungan keluarga. Menurut Zidniyati (2019) pendidikan karakter harus terus di perjelas, diperkuat dan 
diterapkan secara berkelanjutan dan tanpa henti. Banyaknya nilai-nilai yang datang dari luar yang dibawa oleh arus global dan berdampak adanya pertukaran budaya, hal tersebut menuntut seseorang untuk lebih selektif dan harus memegang teguh sebuah prinsip hidup agar tidak mudah terkontaminasi oleh banyaknya pengaruh buruk yang tidak sesuai.

Lickona dalam Sudrajat (2011: 49) mengemukakan beberapa alasan penting tentang mengapa pendidikan karakter harus dilaksanakan, yaitu: 1) Sebagai salah satu cara untuk meningkatkan prestasi akademik, 2) sebagai persiapan untuk seseorang dapat hidup dengan baik di ruang lingkup masyarakat yang luas, 3) agar seseorang memiliki nilai-nilai karakter yang baik sehingga kehidupannya menjadi lebih bermakna, 4) sebagai pembelajaran nilainilai budaya yang merupakan bagian dari peradaban bangsa.

\section{Penguatan Pendidikan Karakter di Indonesia}

Untuk mengatasi dan mencegah adanya kemerosotan moral bangsa dan juga sebagai dukungan dalam mewujudkan cita-cita pembangunan karakter, sebagaimana yang termaktub dalam pancasila dan UUD 1945, pemerintah Indonesia menjadikan program Penguatan Pendidikan Karakter (PPK) sebagai salah satu program penting dalam upaya pembangunan bangsa dan nasional. Pendidikan karakter dijadikan sebagai pijakan dalam mewujudkan visi pembangunan nasional, yaitu untuk menjadikan masyarakat yang berakhlak mulia, beretika, bermoral, berbudaya dan beradab sesuai falsafah pancasila. Pembentukan dan pengembangan karakter harus terus menerus dilakukan dari seluruh ruang pendidikan (keluarga, masyarakat, sekolah) Penanaman nilai-nilai karakter di usia dini dalam lingkungan keluarga adalah untuk pembentukan karakter pada anak. Penanaman di usia remaja adalah untuk pengembangan nilai-nilai karakter tersebut. Sedangkan pendidikan karakter pada usia dewasa yaitu untuk pemantapan karakter dalam diri seorang individu. Hal ini dikarenakan pendidikan karakter adalah pendidikan yang never ending (tidak pernah berakhir). (Kristiawan, 2013: 14-15).

Pendidikan karakter berkaitan dengan revolusi mental, sebagaimana yang disampaikan oleh Presiden Joko Widodo mengenai definisi dari revolusi mental yang dalam penjabarannya meliputi tiga dimensi pembangunan manusia Indonesia, yaitu sehat, cerdas dan berkepribadian. Ketiganya merupakan upaya untuk menjadikan Indonesia sebagai bangsa yang 
berkarakter, dan yang menjadi landasan utama dalam sebuah revolusi mental adalah pendidikan, mengingat bahwa pendidikan memangku peranan penting dalam pembentukan mental dan karakter anak bangsa (Kristiawan, 2013: 15).

Mengenai penguatan pendidikan karakter di Indonesia tertuang dalam Peraturan Presiden Republik Indonesia Nomor 87 Tahun 2017 Tentang Penguatan Pendidikan Karakter (Lasia, 2019). Peraturan Presiden tersebut bertujuan untuk membentuk bangsa yang berbudaya melalui penanaman nilainilai karakter yang meliputi aspek keagamaan, kemanusiaan dan kewarganegaraan. Kementrian pendidikan dan kebudayaan (Kemdikbud) dalam jogloabang (2018) mengenai Perpres (Peraturan Presiden) tersebut bahwa program Penguatan Pendidikan Karakter (PPK) adalah program pendidikan yang merupakan tanggung jawab setiap satuan lembaga pendidikan guna membangun, membentuk dan memperkuat karakter peserta didik melalui olah hati (etik) yaitu aspek kerohanian yang meliputi iman dan takwa kepada Tuhan Yang Maha Esa, olah pikir (literasi) yaitu keunggulan akademis yang merupakan hasil dari setiap pembelajaran, olah raga (kinestetik) yaitu kondisi yang sehat serta dapat berinteraksi dengan aktif, olah rasa (estetis) yaitu memiliki integritas moral, berkesenian dan berbudaya, dengan melibatkan seluruh pihak (keluarga, sekolah dan masyarakat). (Purnomo et al., 2019: 157) dengan adanya program penguatan pendidikan karakter (PPK) diharapkan kepada peserta didik agar tidak hanya menerima informasi dan meniru saja, namun juga peserta didik dapat memahami, menemukan makna dan dapat mengembangkan potensi diri dan pengetahuan yang diperoleh.

Dalam program Penguatan Pendidikan Karakter yang di atur dalam Perpres Nomor 87 Tahun 2017, terdapat 5 nilai utama karakter prioritas PPK, yaitu:

1. Religius, yaitu berbakti dan beriman kepada Tuhan yang maha Esa.

2. Integritas, yaitu menjadi individu yang dapat dipercaya, baik perkataan, perbuatan, pekerjaan.

3. Nasionalis, yaitu menjadikan kepentingan nasional dan bangsa di atas kepentingan pribadi.

4. Mandiri, yaitu upaya untuk tidak bergantung dengan orang lain.

5. Gotong royong, yaitu semangat untuk bekerja sama dalam menyelesaikan setiap pekerjaan. 
Kelima nilai karakter prioritas PPK tersebut bukanlah nilai yang berkembang secara terpisah atau berdiri sendiri, melainkan nilai-nilai tersebut harus terintegrasi satu dengan yang lainnya agar bisa berkembang dan dapat membentuk keutuhan diri (Jogloabang, 2018).

\section{Nilai-Nilai dan Prinsip dalam Pendidikan Karakter}

Dalam pendidikan karakter terdapat berbagai macam komposisi nilai, diantaranya yaitu nilai agama, nilai moral, nilai kewarganegaraan dan nilai umum (Koesoema, 2010: 205). Adapun Fahmy et al. dalam Amran et al. (2019: 234), mengemukakan nilai-nilai yang ada dalam pendidikan karakter yang selaras dengan rumusan nilai-nilai pendidikan karakter yang diatur dalam Peraturan Presiden Nomor 87 Tahun 2017 dengan menerapkan nilai-nilai pancasila sebagai upaya untuk membangun karakter bangsa sehingga dapat membentuk generasi yang berkualitas yaitu:

1. Religious

Patuh terhadap agama yang dianutnya, hidup rukun dan menghargai pemeluk agama lain.

2. Toleransi antar sesama dan terhadap keberagaman

Menghargai adanya perbedaan suku, ras, adat istiadat, dan segala sesuatu yang berbeda.

3. Jujur

Menjadi seseorang yang selalu dapat dipercaya, baik perkataan maupun tindakan.

4. Kerja keras

Bersungguh sungguh dalam menyelesaikan suatu tugas serta melakukan dengan sebaik-baiknya.

5. Kreatif

Memiliki ide-ide untuk melakukan pembaharuan terhadap apa yang telah ada.

6. Disiplin

Taat terhadap peraturan yang berlaku dan senantiasa berprilaku tertib.

7. Mempunyai rasa ingin tahu

Selalu ingin mengetahui secara mendalam terhadap apa yang telah ia tahu.

8. Mandiri

JIEBAR : Journal of Islamic Education: Basic and Applied Research

Vol. 01, Nomor 02, Oktober2020 
Dapat menyelesaikan sesuatu dengan sendiri dan tidak bergantung kepada siapa pun.

9. Bertanggung jawab

Melakukan apa yang telah menjadi tugas dan kewajibannya, baik itu terhadap agama, bangsa, masyarakat dan diri sendiri.

10. Cinta damai

Menciptakan suasana yang nyaman, aman, tentram.

11. Komunikatif

Mampu berinteraksi dengan baik atau bersahabat dengan orang lain.

12. Peduli lingkungan

Menjaga lingkungan sekitar, mencegah kerusakan dan melakukan perbaikan terhadap lingkungan yang telah rusak.

13. Peduli sosial

Peduli sesame dengan saling tolong menolong dan memberi bantuan kepada masyarakat yang membutuhkan.

14. Gemar membaca

Menyediakan waktu untuk membaca apapun yang bermanfaat terutama buku, karena buku adalah gudangnya ilmu dan buku adalah jendela dunia.

15. Cinta tanah air

Menunjukan sikap setia dan peduli serta mengharagai Negaranya.

16. Berprestasi

Menjadi manusia yang berguna terhadap masyarakat serta menghargai keberhasilan orang lain.

17. Memiliki semangat kebangsaan

Menganggap bahwa kepentingan bangsa dan Negara ada di atas kepentingan pribadinya.

18. Demokratis

Tidak membeda-bedakan akan hak dan kewajiban dirinya dengan orang lain.

Dalam pengembangan pendidikan karakter juga terdapat prinsipprinsip yang harus diperhatikan dan dilaksanakan oleh para pelaku pendidikan agar hasil dari pendidikan karakter dapat tercapai secara efektif dan optimal, diantaranya adalah: 
1. Mendemonstrasikan nilai-nilai pendidikan karakter sebagai tumpuan awal (Setiawan, 2014: 3).

2. Berkelanjutan, proses pendidikan karakter adalah proses pendidikan yang tiada henti, dilakukan bukan hanya dalam lembaga pendidikan saja namun juga harus ditanamkan sejak dini pada anak dalam lingkungan keluarga, bahkan pendidikan ini baru dikatakan selesai hingga seseorang telah meninggal dunia. Pendidikan karakter dapat disebut dengan pendidikan sepanjang hayat (Sri Judiani, 2010: 285).

3. Melibatkan seluruh elemen (keluarga, masyarakat, sekolah, lingkungan sekitar) agar adanya keterpaduan dalam penanaman dan pembentukan karakter seorang individu.

4. Nilai-nilai pendidikan karakter harus di artikan secara menyeluruh dengan memperhatikan pada pikiran, perasaan dan perbuatan atau perilaku (Nashihin, 2017: 29)

5. Menciptakan lingkungan yang peduli dan mendukung adanya pendidikan karakter.

6. Menumbuhkan dan membangun motivasi dalam diri peserta didik serta memberi dukungan penuh terhadapnya (Japar et al., 2018: 65).

7. Di dalam lembaga pendidikan, nilai-nilai pendidikan karakter harus dibubuhkan dalam setiap mata pelajaran serta pada segala bentuk kegiatan didalam dan luar jam pembelajaran (Sri Judiani, 2010: 285).

8. Proses pelaksanaan pendidikan karakter dilakukan secara menyenangkan dan aktif.

\section{E. Tujuan penguatan pendidikan karakter}

Secara umum tujuan dari dilaksanakannya pendidikan karakter yaitu untuk membentuk seseorang atau sebuah bangsa yang bermoral, berakhlak mulia, berbudi pekerti luhur, religius, tangguh, toleran, nasionalis, kompetetif, berpengetahuan dan dapat berkembang secara dinamis. Adanya pendidikan karakter di Indonesia yaitu untuk mencapai tujuan dari pendidikan nasional yakni untuk mengembangkan potensi peserta didik agar menjadi manusia yang berbakti kepada Tuhan Yang Maha Esa, cakap, terampil, bertanggung jawab, kreatif, berakhlak mulia, sehat, berilmu, mandiri dan menjadi warga Negara yang demokratis (Risqi et al., 2020). 
Berikut adalah tujuan pendidikan karakter yang selaras dengan rumusan Perpres Nomor 87 Tahun 2017, antara lain:

1. Menanamkan perilaku dan kebiasaan yang terpuji yang senada dengan nilai-nilai agama, budaya dan bangsa, sehingga dapat menjadi manusia yang baik di hadapan Tuhan Yang Maha Esa juga di hadapan sesama manusia.

2. Memperbaiki nilai-nilai buruk yang telah terbentuk dalam diri seseorang agar berubah menjadi nilai-nilai yang positif (Laksono, 2019).

3. Mengembangkan potensi dan nilai-nilai seorang individu agar menjadi manusia yang berbudaya (Maunah, 2014: 91).

4. Mengembangkan dan memperkuat kompetensi dan potensi bangsa yang meliputi seluruh elemen yaitu keluarga, masyarakat, pendidik, tenaga kependidikan dan peserta didik.

5. Mengembangkan program pendidikan nasional yang bercita-cita untuk menjadikan pendidikan karakter sebagai pokok utama dalam penyelenggaraan sistem pendidikan.

6. Dalam program PPK di Indonesia yaitu untuk membekali peserta didik sebagai generasi emas Indonesia pada tahun 2045 yang memiliki nilainilai karakter dan berjiwa pancasila guna menghadapi perkembangan zaman dan perubahan-perubahan yang akan terjadi di masa mendatang (Jogloabang, 2018).

7. Penguatan karakter individu untuk mengahadapi persaingan zaman dengan kompetensi abad 21, yakni kreatif, komunikatif, berpikir kritis dan kolaboratif (Anshori, 2017).

\section{F. Implementasi penguatan pendidikan karakter}

Selain dalam lingkungan keluarga dan masyarakat, lembaga pendidikan juga menjadi figur yang sangat berpengaruh dalam pembentukan karakter seorang individu. Yang dapat menanamkan nilai-nilai karakter pada peserta didiknya melalui pembelajaran dan segala bentuk kegiatan yang ada di dalam lembaga pendidikan tersebut. Lembaga pendidikan juga diharapkan menjadi mesin pembentuk manusia-manusia yang unggul dan berkarakter guna untuk menjadi generasi penerus di masa yang akan datang. 
Dalam implementasi pendidikan karakter di sebuah lembaga pendidikan, harus melibatkan seluruh elemen dan komponen lembaga tersebut juga komponen dari pendidikan itu sendiri, antara lain kurikulum, proses pembelajaran, cara komunikasi, pengelolaan sumber daya, sarana dan prasarana, etika kerja warga sekolah, lingkungan dan budaya sekolah, dan lainnya (Kosim, 2011). Menurut Sofanudin (2015) dalam melaksanakan kurikulum pendidikan karakter sebaiknya pembelajaran mengenai nilai-nilai dan moral harus berhubungan dengan sistem lembaga pendidikan secara menyeluruh dan diajarkan sebagai subjek yang tidak berdiri sendiri tetapi juga harus berkaitan dengan kurikulum lembaga pendidikan tersebut secara keseluruhan. Di samping itu, Riyanto dalam (Dalyono \& Lestariningsih, 2017: 40) berpendapat bahwa ada beberapa pola atau model yang dapat dipilih dan diterapkan dalam penyelenggaraan pendidikan karakter di sebuah lembaga pendidikan, , yaitu:

1. Model integrasi, yaitu dengan menyatukan nilai-nilai pendidikan karakter ke dalam setiap mata pelajaran yang ada.

2. Model otonomi, yaitu menjadikan pendidikan karakter menjadi sebuah mata pelajaran yang berdiri sendiri.

3. Model ekstrakulikuler, yaitu melalui kegiatan tambahan diluar jam belajar yang berorientasi pada pembinaan karakter peserta didik.

4. Model kolaboratif, yaitu menggabungkan model integrasi, otonomi dan kolaboratif dalam seluruh kegiatan yang ada di sekolah.

Darmuin (Dalyono \& Lestariningsih, 2017: 40-41) juga mengemukakan beberapa model implementasi dalam pelaksanaan pendidikan karakter, yaitu:

1. Keteladanan, baik dalam lembaga satuan pendidikan formal maupun non formal harus menunjukkan keteladan akan nilai-nilai dari pendidikan karakter yang akan dikembangkan. Perilaku seorang pendidik dan tenaga kependidikan harus dapat dijadikan contoh dan teladan bagi peserta didik.

2. Pembelajaran di dalam kelas, setiap materi ajar yang disampaikan atau segala bentuk kegiatan pembelajaran di kelas harus dapat membubuhkan nilai-nilai pendidikan karakter sehingga pembelajaran tersebut menjadi optimal dengan mengembangkan kemampuan peserta didik dalam aspek kognitif, afektif dan psikomotorik. 
3. Pengintegrasian pendidikan karakter ke dalam setiap mata pelajaran yang ada dengan memastikan bahwa pembelajaran setiap mata pelajaran juga harus dapat membentuk karakter peserta didik.

4. Pendidikan karakter dijadikan sebagai satu kegiatan ekstrakulikuler di luar jam belajar siswa. Hal ini diharapkan dapat memaksimalkan program penguatan pendidikan karakter di dalam sebuah lembaga pendidikan.

5. Bentuk penguatan dapat dimulai dari ruang lingkup yang kecil terlebih dahulu sebelum terjun dalam ruang lingkup yang lebih luas. Miasalnya dengan penataan lingkungan belajar yang mendukung dan membangun karakter peserta didik.

Di Indonesia, tentang program penguatan pendidikan karakter yang di atur dalam Perpres Nomor 87 Tahun 2017 juga menjelaskan mengenai ruang lingkup dalam penyelenggaraan PPK, yaitu meliputi satuan pendidikan formal, non formal dan informal. Pelaksanaan PPK dalam satuan pendidikan formal yaitu meliputi kegiatan intrakulikuler (pelaksanaan pembelajaran dan penggunaan metode pembelajaran yang sesuai dengan kurikulum yang berlaku), kokulikuler (kegiatan pengayaan atau pendalaman terhadap kegiatan pembelajaran), dan ekstrakulikuler (pengembangan bakat, minat, potensi peserta didik) yang dilakukan didalam atau luar lingkungan pendidikan. Sedangkan pelaksanaan PPK di dalam satuan pendidikan informal dan formal yaitu dengan menanamkan nilai-nilai karakter dalam proses pembelajaran dan terhadap metode-metode belajar yang digunakan (Jogloabang, 2018).

\section{KESIMPULAN}

Pendidikan karakter mempunyai peranan penting dalam membentuk manusia-manusia yang berkualitas, bernilai, bermoral dan berbudaya. Pendidikan karakter harus diajarkan dan ditanamkan dalam diri seorang individu sejak dini, agar menjadi bekal untuk hidup di dalam masyarakat yang luas. Pemerintah Indonesia mencanangkan program gerakan Penguatan Pendidikan Karakter (PPK) yang memiliki lima nilai karakter prioritas yaitu, religius, mandiri, gotong royong, integritas dan nasionalis, yang harus dilaksanakan dalam setiap lembaga satuan pendidikan. Program tersebut bertujuan untuk menciptakan generasi emas Indonesia agar dapat bersaing untuk menghadapi arus globalisasi. Pelaksanaan pendidikan karakter bukanlah 
sesuatu yang instan, pendidikan tersebut harus dilakukan secara terus menerus dan tidak akan pernah berakhir. Untuk mendapatkan hasil yang optimal pendidikan karakter harus melibatkan dukungan dari berbagai aspek yaitu keluarga, sekolah dan masyarakat.

\section{REFERENSI}

Afandi, R. (2011). Integrasi Pendidikan Karakter dalam Pembelajaran IPS di Sekolah Dasar. Pedagogia, 1.

Ainissyifa, H. (2014). Pendidikan Karakter Dalam Perspektif Pendidikan Islam. Jurnal Pendidikan Universitas Garut, 08, 1-26.

Ainiyah, N. (2013). Pembentukan Karakter Melalui Pendidikan Agama Islam. Jurnal Studi-Studi Islam, 13, 25-38.

Amran, Jasin, I., Perkasa, M., Satriawan, M., \& Irwansyah, M. (2019). Model Pembelajaran Berbasis Nilai Pendidikan Karakter Untuk Generasi Indonesia Abad 21. Lentera Pendidikan, 22, 233-242.

Anshori, I. (2017). Penguatan Pendidikan Karakter Di Madrasah. Islamic Education Jurnal, 1(2), 63-74. Https://Doi.Org/10.21070/Halaqa.V1i2.1243

Dahliyana, A. (2017). Penguatan Pendidikan Karakter Melalui Kegiatan Ekstra Kulikuler Di Sekolah. Jurnal Sosioreligi, 15.

Dalyono, B., \& Lestariningsih, Enny Dwi. (2017). Implementasi Penguatan Pendidikan Karakter Di Sekolah. 03, 33-42.

Farida, S. (2016). Pendidikan Karakter Dalam Prespektif Islam. 1(1), 198-207.

Hartatik, Y. (2014). Implementasi Pendidikan Karakter Di Kantin Kejujuran. Penerbit Gunung Samudera.

Japar, M., Zulela, \& Mustoip, S. (2018). Implementasi Pendidikan Karakter. Jakad Media Publishing.

Jogloabang. (2018). Perpres 87 Tabun 2017 Tentang Penguatan Pendidikan Karakter. Https://Www.Jogloabang.Com/Pendidikan/Perpres-87-2017-

Penguatan-Pendidikan-Karakter

Judiani, S. (2010). Implementasi Pendidikan Karakter di Sekolah Dasar Melalui Penguatan Pelaksanaan Kurikulum. Pendidikan Dan Kebudayaan, 16

Julaiha, S. (2014). Implementasi Pendidikan Karakter Dalam Pembelajaran. 14(2), 226-239.

Koesoema, D. (2010). Pendidikan Karakter: Strategi Mendidik Anak Di Zaman

JIEBAR : Journal of Islamic Education: Basic and Applied Research

Vol. 01, Nomor 02, Oktober2020 
Global (2nd Ed.). Grasindo.

Kosim, M. (2011). Urgensi Pendidikan Karakter. Karsa, IXI.

Kristiawan, M. (2013). Telaah Revolusi Mental Dan Pendidikan Karakter Dalam Pembentukkan Sumber Daya Manusia Indonesia Yang Pandai Dan Berakblak Mulia. Ta'dib, 18.

Laksono, Tri Hayu. (2019). Implementasi Peraturan Presiden No 87 Tahun 2017 Tentang Penguatan Pendidikan Karakter Di Sekolah Dasar Magelang. 87.

Lasia, I. M. (2019). Geguritan: Penguatan Pendidikan Karakter (Sesuai Peraturan Presiden Ri Nomor 87 Tabun 2017). Cv Grapena Karya.

Majid, N. (2019). Penguatan Karakter Melalui Local Wisdom Sebagai Budaya Kewarga Negaraan. Yayasan Ahmar Cendekia Indonesia.

Maunah, B. (2014). The Implementation Of Character Education In The Formation Of Students' Holistic Personality. Jurnal Pendidikan Karakter, 90-101.

Nashihin, H. (2017). Pendidikan Karakter Berbasis Budaya Pesantren. Formaci.

Neolaka, Amos Dan Grace Amialia. (2017). LANDASAN PENDIDIKAN : Dasar Pengenalan Diri Sendiri Menuju Perubahan Hidup. Kencana.

Purnomo, A., Muntholib, A., \& Mulianingsih, F. (2019). Pelatihan Pengembangan Perangkat Pembelajaran IPS Berorientasi Pada Perpres Nomor 87 Tabun 2017 Pada Forum Guru Ambarawa. Jurnal Panjar, 1(2), 156-159.

Rachmadyanti, P. (2017). Penguatan Pendidikan Karakter Bagi Siswa Sekolah Dasar Melalui Kearifan Lokal. Jpsd, 3(2), 201-214.

Raharjo, Sabar Budi. (2010). Pendidikan Karakter Sebagai Upaya Menciptakan Akblak Mulia. Pendidikan Dan Kebudayaan, 16, 229-238.

Ramdani, E. (2018). Model Pembelajaran Kontekstual Berbasis Kearifan Lokal Sebagai Penguatan Pendidikan Karakter. Jurnal Pendidikan Ilmu-Ilmu Sosial, 10(1), 1 10.

Risqi, D., Maila, L., Linamro’ah, Azzahra, S., Maftuhatu, Zahro, F., \& Hanan, K. (2020). Pendidikan Karakter Dalam Pembelajaran Matematika. Kalam Hanan.

Rosidatun. (2018). Model Implementasi Pendidikan Karakter. Caramedia Communication.

Setiawan, A. (2014). Prinsip Pendidikan Karakter Dalam Islam (Studi Komparasi Pemikiran Al-Ghazali Dan Burhanuddin Al Zarnuji. Dinamika Ilmu, 14.

JIEBAR : Journal of Islamic Education: Basic and Applied Research

Vol. 01, Nomor 02, Oktober2020 
Sofanudin, A. (2015). Internalisasi Nilai-Nilai Karakter Bangsa Melalui Mata Pelajaran Pendidikan Agama Islam Pada Sma Eks-Rsbi Di Tegal. 1(3), 151163.

Sudarsana, I. K., \& Herawan, Kadek Deddy. (2017). Relevansi Nilai Pendidikan Karakter Dalam Geguritan Suddhamala Untuk. Meningkatkan Mutu Pendidikan Di Indonesia. Penjamin Mutu, 3, 223-236.

Sudrajat, A. (2011). Mengapa Pendidikan Karakter? Jurnal Pendidikan Karakter, 1, 47-58.

Sukiyat. (2020). Pendidikan Kepramukaan Berbasis Pendidikan Karakter. CV. Jakad Media Publishing (Ed.).

Sukiyat. (2020). Strategi Implementasi Pendidikan Karakter. Cv Jakad Media Publishing.

Sulastri. (2018). Nilai Karakter Dalam Pembelajaran Kimia. Syiah Kuala University Press.

Syam, Syamsyunardi Dan Nur. (2019). Pendidikan Karakter Keluarga Dan Sekolah. Yayasan Ahmar Cendekia Indonesia.

Yaumi, M. (2014). Pendidikan Karakter: Landasan, Pilar, Dan Implementasi. Kencana.

Zidniyati. (2019). Penguatan Pendidikan Karakter Di Sekolah Dasar Di Era Revolusi Industri 4.0. Tarbiyatuna, 3.

Zubaedi. (2011). Desain Pendidikan Karakter: Konsepsi Dan Aplikasinya Dalam Lembaga Pendidikan. Kencana.

JIEBAR : Journal of Islamic Education: Basic and Applied Research

Vol. 01, Nomor 02, Oktober2020 